\title{
Spatial and Temporal Incidences of Pineapple mealybug wilt-associated viruses in Pineapple Planting Blocks
}

\author{
D. M. Sether, W. B. Borth, M. J. Melzer, and J. Hu, University of Hawaii at Manoa, Plant and Environmental Pro- \\ tection Sciences, Honolulu 96822
}

\begin{abstract}
Sether, D. M., Borth, W. B., Melzer, M. J., and Hu, J. 2010. Spatial and temporal incidences of Pineapple mealybug wilt-associated viruses in pineapple planting blocks. Plant Dis. 94:196-200.

A complex of Pineapple mealybug wilt-associated viruses (PMWaVs) that can infect pineapple (Ananas comosus) is correlated with reduced yields and mealybug wilt of pineapple. The incidences of PMWaV-1 and PMWaV-2 at planting, fruit harvest, the beginning of the ratoon crop, and ratoon fruit harvest were determined for end, side, and central regions of planting blocks in eight commercial fields. Differences in virus incidence for the three regions at ratoon harvest were highly significant $(P=0.0018)$. Central regions of planting blocks had lower virus incidences at the time of ratoon fruit harvest. Collection of propagation material from the central regions of planting blocks will help to minimize PMWaV incidence in fields planted with this material.
\end{abstract}

A complex of Pineapple mealybug wiltassociated viruses (PMWaVs) has been identified in the Ananas (pineapple) and Pseudoananus genera throughout the pineapple-growing regions of the world $(1,5,7-$ 10,14,18,25,29). Three of these viruses, PMWaV-1, PMWaV-2, and PMWaV-3, have been characterized $(13,14,24)$. PMWaV-2 differs from PMWaV-1 and PMWaV-3 phylogenetically, though all are members of the genus Ampelovirus in the family Closteroviridae $(13,14,24)$. The three PMWaVs can be acquired and transmitted by the pink and gray pineapple mealybugs, Dysmicoccus brevipes (Cockerell) and $D$. neobrevipes Beardsley, respectively $(22,25)$. In Hawaii, the etiology of mealybug wilt of pineapple (MWP), a serious disease in most pineapple-growing regions worldwide, involves mealybug feeding and the presence of PMWaV-2 $(19,20)$. Mealybug feeding by itself or in combination with PMWaV-1 or PMWaV-3 infections in the absence of PMWaV-2 does not result in MWP in Hawaii $(19,25)$. In Australia, the association between PMWaV-2 and MWP is less than $100 \%$, suggesting that other PMWaVs, other strains of PMWaV-2, or other factors may be involved (5). Plants afflicted with MWP may recover from wilt symptoms (4) but remain PMWaV infected. PMWaV infections have been correlated with 5 to $15 \%$ yield reductions in the ratoon crop, even in

Corresponding author: J. S. Hu

E-mail: johnhu@hawaii.edu

Accepted for publication 14 October 2009.

doi:10.1094/PDIS-94-2-0196

(C) 2010 The American Phytopathological Society the absence of MWP symptoms $(17,18,20,26)$. Furthermore, because pineapple is clonally propagated, healthyappearing $\mathrm{PMWaV}$-infected plants provide sources for virus acquisition, perpetuation of yield reductions, and MWP spread $(19,20)$.

Pineapple is typically planted at densities of 60,000 to 90,000 plants/ha and requires 15 to 20 months to produce the first fruit, called the plant crop (15). Following the plant crop, the mother plant that produced the fruit declines while giving rise to one or two ratoons. The first ratoon crop will produce fruit in 12 to 15 months. Second and third ratoon crops are not common in Hawaii due to the build-up of nematodes, fungal and bacterial diseases, and MWP (16). Pineapple plants infected with PMWaVs may be asymptomatic. Therefore, specific virus detection assays are necessary to detect latent infections. Reverse-transcription polymerase chain reaction (PCR) assays have been developed that can detect and are specific for PMWaV-1, PMWaV-2, PMWaV-3, PMWaV-4, and, most recently, PMWaV-5 in infected pineapple plants $(5,25)$. Monoclonal antibodies (MAbs) specific for PMWaV-1 and PMWaV-2 have been used in tissue-blot immunoassays (TBIAs) to test a thousand plants per day $(9,10,18,20)$.

Nearly a decade ago in Hawaii, the incidence of PMWaV-1 and PMWaV-2 in asymptomatic commercially grown pineapples ranged from 0 to 100 and 0 to $20 \%$, respectively, depending on the cultivar (9,18). PMWaV-3 incidence ranged from 0 to $22 \%$ (25). In Hawaii, higher incidences occurred in Smooth Cayenne cultivars while lower incidences were found in the hybrids that have since replaced the
Smooth Cayenne cultivars. Since those surveys were conducted, the Hawaiian pineapple industry has replaced the Smooth Cayenne cultivars with low-acid hybrids. In 2005, commercial pineapple hybrids in Hawaii had PMWaV incidences ranging from 0 to $40 \%$, depending on the hybrid and PMWaV species (25).

The relatively long production cycle from planting of the slips or crowns through ratoon fruit harvest makes the crop vulnerable to mealybug infestation, virus spread, and MWP. Propagation material used to establish new fields is typically collected from existing fields. This practice contributes to an increase in virus incidence over time. Presently, virus indexing of the large numbers of slips and crowns necessary for establishing fields is not practical; thus, alternative strategies to minimize the increase of the PMWaVs are needed.

In a spatial study of virus incidences conducted from 2003 to 2006, we evaluated PMWaV-1 and PMWaV-2 incidences at three locations within the planting blocks of eight fields from the time of planting through ratoon fruit harvest. TBIA assays available for PMWaV-1 and PMWaV-2 provided a means of rapidly processing thousands of samples. There are three PMWaVs present in the commercial hybrid studied, and PMWaV-1 and PMWaV-2 are present at the highest and lowest incidences, respectively (27). Our goal was to determine whether there were regions within planting blocks that were less prone to virus increase over the production cycle and, therefore, more suitable for collection of virus-free propagation material.

\section{MATERIALS AND METHODS}

Spatial analyses of virus incidence. The study was conducted on a commercial pineapple plantation located in Wahiawa on the island of Oahu, HI. All fields used in this study were planted with the lowacid pineapple hybrid MG3. Planting, irrigation, fertilization, pest control, and maintenance were conducted by the plantation using standard methods and rates. Foliar applications of diazinon were made prior to plant crop and ratoon crop fruit harvests. The establishment of ant colonies, which often tend mealybug colonies, was prevented with five broadcast applications of hydramethylnon (Amdro®Pro Fire Ant Bait; BASF) made between the time of 
planting and ratoon fruit harvest, as previously described (21). Timing of the applications were based on detection of ants during scouting and with traps, as previously described $(21,28)$ Studies were conducted in eight different fields over a period of 30 months spanning the time of planting in 2003 through harvest of the ratoon fruit in 2006. Fields 1 and 2, 3 and 4, 5 and 6 , and 7 and 8 were located in the northern, eastern, southern, and western parts of the plantation, respectively. Fields in the same part of the plantation were approximately $2 \mathrm{~km}$ apart. Distances between fields in different parts of the plantation varied from 4 to $12 \mathrm{~km}$. Plants were planted on $36-\mathrm{cm}$ centers and plants in rows of the same bed were offset from one another (Fig. 1). Pineapple plants were grown in planting blocks of about $32 \mathrm{~m}$ in width, each consisting of 56 rows of plants in 28 raised beds (Fig. 1). Planting block lengths varied from 300 to $400 \mathrm{~m}$. The ends and sides of planting blocks were bordered by unpaved service roads. One planting block of similar size on level terrain was selected in each of eight fields. Previously, we have shown that infected plants are generally distributed randomly at the time of planting (20). To assure coverage of the entire region of interest, sampling of plants for presence of viruses was conducted along a systematic zigzag W pattern (2) in the end, side, and central regions within each planting block (Fig. 1). Briefly, sampling began by pulling a leaf from a plant in each row of a bed, then moving $1 \mathrm{~m}$ up or down the row and sampling a plant in each row of the next bed. The process continued until the entire region of interest was spanned and 100 leaves per region were collected. This method also simplified finding the same marked plants for resampling on later collection dates. Four replicates, each consisting of 100 plants, were collected from each region within a planting block. In total, 9,600 plants from eight planting blocks in eight different fields were sampled. Plants were marked with flags and the same plants were sampled at 3 months post planting, near plant crop fruit harvest, 3 months after plant crop harvest, and at ratoon fruit harvest. During the ratoon crop, the initial mother plants gave rise to one or more ratoons. Only one ratoon from each mother plant was sampled. Each sample consisted of a single leaf, 20 to 30 $\mathrm{cm}$ in length if collected from the plant or $10 \mathrm{~cm}$ in length if collected from the crown of the fruit. The cut end of leaves were blotted onto Nitro Bind membrane (Osmonics, Inc.) and the blots assayed for PMWaV-1 and PMWaV-2 using virus- specific MAbs 35-6-3 and 63-2-2, respectively, in TBIA as previously described $(9,20)$.

Statistical analyses. Virus incidence was evaluated with repeated-measures analysis of variance (ANOVA) with between-subjects factors using the General Linear Model procedure (proc GLM) in SAS (ver. 8.1; SAS, Inc.). Mauchly's test of sphericity was included to evaluate whether a common spherical covariance matrix was met in each of the analyses. Deviation was used as the contrast scheme for the transformation matrix. In addition to multivariate analyses, $P$ values adjusted with the Huynh-Feldt Epsilon (H-F) correction factor were used for univariate analyses interpretation. All designs were balanced. Virus incidence based on four replicates (100 plants/replicate) for each of the three locations in the planting blocks of eight different fields was compared using the same group of plants at four different stages from planting to ratoon fruit harvest. The MODEL statement was IncP IncPH IncR IncRH = Location Field Location $\times$ Field, which refers to the virus incidence at planting $(\mathrm{P})$, plant crop fruit harvest $(\mathrm{PH}), 3$ months after plant crop fruit harvest $(\mathrm{R})$, ratoon fruit harvest $(\mathrm{RH})$, the location of the plants in the planting block (end, side, or center), and the field (1 to 8).

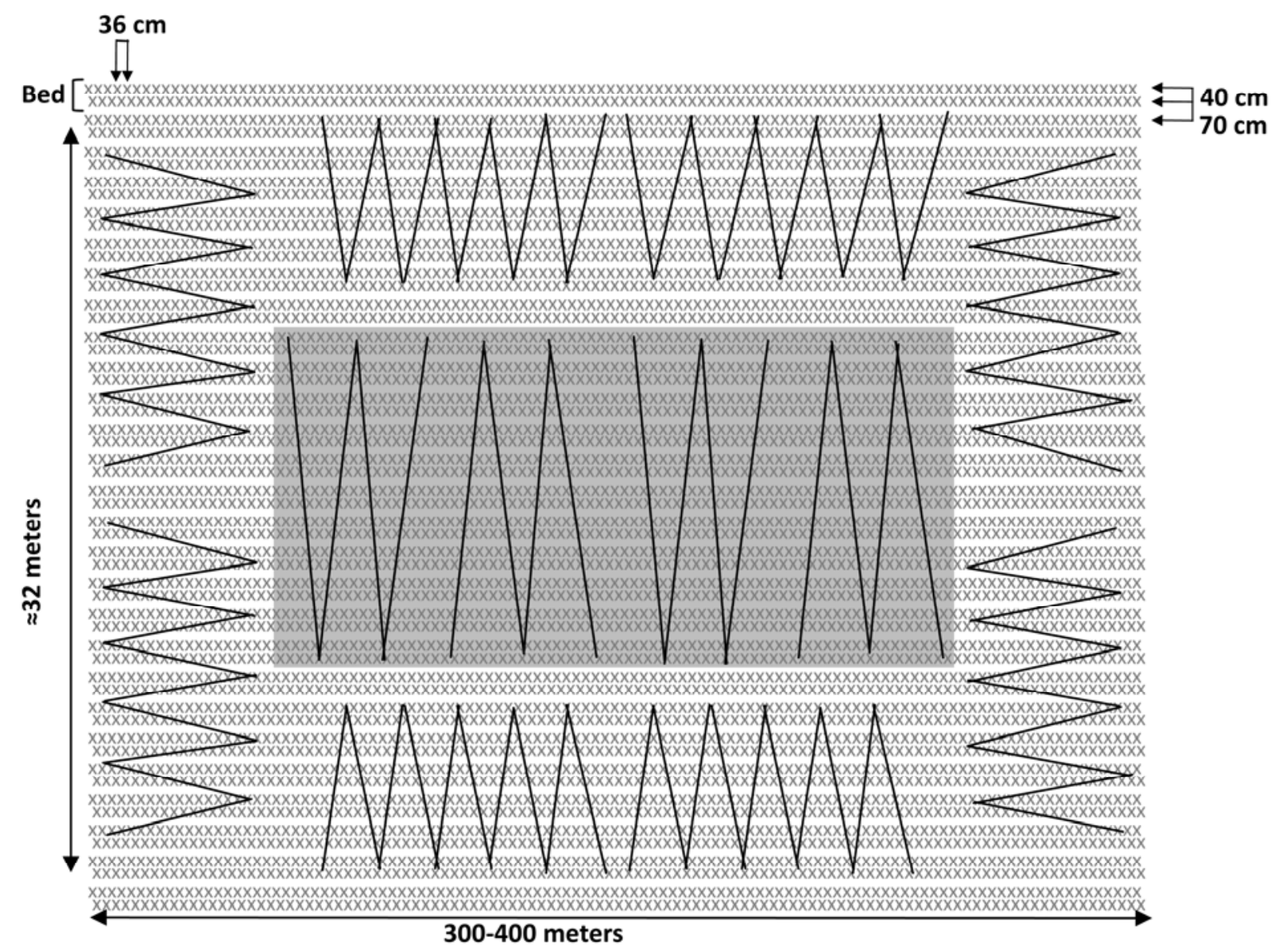

Fig. 1. Layout of a planting block composed of 28 beds, each with two rows of plants denoted by x. Dark lines represent sampling patterns used for end, side, and central (shaded) regions of the planting block. Each sampling pattern represents 100 plants surveyed at 3 months after planting, 2 months before plant crop fruit harvest, 3 months into the ratoon crop, and at ratoon fruit harvest. 
The incidences of PMWaV-1 and PMWaV2 were analyzed separately.

\section{RESULTS}

The $\chi^{2}$ approximation for PMWaV-1 and PMWaV-2 incidences from Mauchly's sphericity tests were 171.15 and 207.60, respectively, with 5 degrees of freedom, and had associated probabilities of less than 0.001. Based on these results, multivariate rather than univariate analyses results are presented.

At the time of planting, virus incidence in sides, ends, and central regions of the planting blocks were similar, although the incidences of each PMWaV were slightly different between fields. The mean incidence for PMWaV-1 and PMWaV-2 across all fields, locations, and replicates at the beginning of the study was 16.78 and $9.19 \%$, respectively. Across the eight fields evaluated, the mean increase in PMWaV-1 was $1.59,0.72$, and $0.09 \%$ for plants located in the side, end, and central regions of the planting blocks, respectively, for the 30 months spanning planting through ratoon fruit harvest. Increases in PMWaV-2 incidence of 0.75 and $0.3125 \%$ in the side and end regions, respectively, were half those of PMWaV-1. The mean PMWaV-2 incidence in the central regions of the fields was $9.3 \%$ and did not change during the 30-month study.

The effects of crop period on PMWaV-1 and PMWaV-2 incidence over a 30-month period spanning 3 months post planting until the harvest of the ratoon fruit crop were highly significant $(P<0.0001)$, indicating that changes in PMWaV incidences had occurred as a function of crop period (Table 1). These changes corresponded to increases in the incidences of PMWaV-1 and PMWaV-2 over time (Table 2), despite the foliar applications of diazinon delivered prior to plant and ratoon fruit harvests for mealybug control and applications of Amdro®Pro ant bait throughout the cropping cycle. For both viruses, the $P$ values obtained from multivariate analyses $(P=$ 0.0018 and 0.0005 for PMWaV-1 and PMWaV-2, respectively) showed that changes in virus incidences across crop periods were affected by location within the planting block (Table 1). The greatest increases in PMWaV-1 incidence occurred along the side regions of the planting

Table 1. Wilk's Lambda test statistics from multivariate analyses for the within-subject and interactive effects of various factors on Pineapple mealybug wilt associated virus-1 (PMWaV-1) and PMWaV-2 incidences in pineapple from 3 months after planting until ratoon fruit harvest at 30 months

\begin{tabular}{lcrrrr}
\hline Factor & Value $^{\mathbf{a}}$ & $\boldsymbol{F}$ value & $\mathbf{N u m ~ d f}^{\mathbf{b}}$ & Den df $^{\mathbf{c}}$ & $\boldsymbol{P}>\boldsymbol{F}^{\mathbf{d}}$ \\
\hline PMWaV-1 & & & & & \\
$\quad$ Crop period & 0.64596264 & 12.79 & 3 & 70.00 & $<0.0001$ \\
Crop period $\times$ location & 0.74385162 & 3.72 & 6 & 140.00 & 0.0018 \\
Crop period $\times$ field & 0.67620809 & 1.40 & 21 & 201.55 & 0.1206 \\
$\quad$ Crop period $\times$ location $\times$ field & 0.61762092 & 0.88 & 42 & 208.42 & 0.6894 \\
PMWaV-2 & & & & & \\
$\quad$ Crop period & 0.64382104 & 12.91 & 3 & 70.00 & $<0.0001$ \\
Crop period $\times$ location & 0.71367475 & 4.29 & 6 & 140.00 & 0.0005 \\
Crop period $\times$ field & 0.57488750 & 2.04 & 21 & 201.55 & 0.0062 \\
Crop period $\times$ location $\times$ field & 0.47643906 & 1.41 & 42 & 208.42 & 0.0622 \\
\hline
\end{tabular}

a Wilk's Lambda test statistic.

b Wilk's Lambda test numerator degrees of freedom.

c Wilk's Lambda test denominator degrees of freedom.

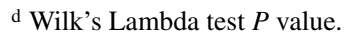

blocks, whereas central regions had the lowest increases (Table 2). The magnitude of the differences between the side and central or end regions increased with crop period. Similar differences were noted for PMWaV-2, although the magnitude of difference between the initial incidence and the incidence at ratoon fruit harvest was much less than that of PMWaV-1 (Table 2). This strongly suggests that initial incidence, in addition to location, is a factor in the magnitude of virus increase across the crop periods. Not all fields showed significant increases in PMWaV-2 incidences; therefore, the change in PMWaV-2 incidence across crop period significantly depended on the field $(P=$ 0.0062 ). In contrast, field was not a significant factor for PMWaV-1 incidence across crop period $(P=0.1206$; Table 1$)$. Location did not interact with field across crop periods for PMWaV-1 but a significant interaction of location with field and crop period was detected for PMWaV-2 (Table 1). This interaction effect is most likely the result of increases in PMWaV-2 incidence occurring only in some fields or in some locations of planting blocks (Table 2).

Repeated measures ANOVA, which pooled the effects of crop period, showed that there were significant main effects for location within the planting block $(P=$ $0.0250)$ and field $(P<0.0001)$ for PMWaV-1 and field $(P<0.0001)$ for PMWaV-2. (Table 3). In general, virus incidences increased with each crop period. Central regions of planting blocks had the lowest incidences of the three regions at the time of ratoon fruit harvest, 30 months after planting. The magnitude of virus increase depended on crop stage, location within the planting blocks, and initial virus incidence.

\section{DISCUSSION}

Based on our findings, the central regions of planting blocks are the preferred

Table 2. Mean incidences (\%) of Pineapple mealybug wilt associated virus-1 (PMWaV-1, first number) and PMWaV-2 (second number) from 3 months post planting through the harvest of the ratoon crop in three different regions (side, end, and center) within the pineapple planting blocks pooled across eight fields and eight fields pooled across three locations within the planting blocks

\begin{tabular}{|c|c|c|c|c|c|}
\hline \multirow[b]{3}{*}{ Location $^{b}$} & \multicolumn{4}{|c|}{ Incidence of PMWaV-1/PMWaV-2 (\%) } & \multirow[b]{3}{*}{ Change in incidence $(\%)$} \\
\hline & \multicolumn{2}{|c|}{ Plant crop } & \multicolumn{2}{|c|}{ Ratoon crop } & \\
\hline & 3 months & 11 months & 19 months & 30 months & \\
\hline \multicolumn{6}{|l|}{ Region } \\
\hline End & $17.1 / 9.4$ & $18 / 9.8$ & $18.2 / 9.8$ & $18.7 / 10.1$ & $1.6 / 0.7$ \\
\hline Side & $16.4 / 8.9$ & $16.8 / 9.1$ & $17.2 / 9.3$ & $17.5 / 9.4$ & $1.1 / 0.5$ \\
\hline Central & $16.8 / 9.2$ & $16.8 / 9.2$ & $16.8 / 9.2$ & $16.9 / 9.2$ & $0.1 / 0.0$ \\
\hline \multicolumn{6}{|l|}{ Field } \\
\hline 1 Northern & $20.4 / 7.5$ & $21.2 / 7.8$ & $21.3 / 7.8$ & $22.2 / 8.0$ & $1.8 / 0.5$ \\
\hline 2 Northern & $15.7 / 10.1$ & $16.5 / 10.4$ & $16.6 / 10.4$ & $16.8 / 10.5$ & $1.1 / 0.4$ \\
\hline 3 Eastern & $18.5 / 10.3$ & $19.0 / 10.8$ & $19.0 / 10.8$ & $19.4 / 10.9$ & $0.9 / 0.6$ \\
\hline 4 Eastern & $15.5 / 9.3$ & $15.5 / 9.3$ & $15.5 / 9.3$ & $15.7 / 9.3$ & $0.2 / 0.0$ \\
\hline 5 Southern & $16.1 / 10.1$ & $16.3 / 10.3$ & $16.3 / 10.3$ & $16.8 / 10.9$ & $0.7 / 0.8$ \\
\hline 6 Southern & $17.9 / 8.8$ & $18.0 / 8.8$ & $18.0 / 8.8$ & $18.3 / 8.8$ & $0.4 / 0.0$ \\
\hline 7 Western & $15.3 / 8.4$ & $15.8 / 8.4$ & $16.0 / 8.4$ & $16.2 / 8.4$ & $0.9 / 0.0$ \\
\hline 8 Western & $15.0 / 9.0$ & $15.3 / 9.3$ & $15.3 / 9.3$ & $15.3 / 9.3$ & $0.3 / 0.3$ \\
\hline
\end{tabular}

a Number of months after field was planted.

${ }^{\mathrm{b}}$ Field identifier and region of the plantation where the field was located. 
locations from which to collect planting material with the lowest virus incidence. If initial virus incidence is very low, the effect of location within planting blocks may be less important, as shown for PMWaV-2 in this study. In the case of PMWaV-1, which had a mean incidence of $17 \%$, location effects within planting blocks by the end of the ratoon crop were statistically significant, with centrally located plants having the lowest virus incidence. Virus incidence also increased over time with crop cycle; therefore, collection of propagation material from central regions of fields with the lowest incidences and from the earliest crop period provides the most effective way to minimize virus incidences in propagation material used to plant new fields. Only PMWaV-2 showed interaction effects between field and location. This may have been due to spread of virus in some fields or locations within some planting blocks but not in others. As has previously been shown, mealybugs are not distributed uniformly across fields $(3,4,21)$. This uneven distribution coupled with the lower initial incidence of PMWaV-2 may result in more localized effects on virus spread. Regardless of the lower incidences or differences between fields, the overall spatial pattern of virus incidence at planting and at ratoon harvest was the same for both viruses; central regions of planting blocks always had the lowest incidence of virus.

The detection of PMWaV by TBIA is affected by virus titer (9). Previously, we established that infections could be detected about 1 month after healthy plants were exposed to viruliferous mealybugs $(19,20,22)$. Once a plant is infected, detection of the virus in the leaf bases or crowns is consistent and highly repeatable in our hands $(9,23)$. If, in the study reported here, infections were initially missed because of a new infection, any assays conducted at least 1 month later would detect such infections. Additionally, the same number of samples were collected from each region and field; if infections were not detected, one could assume that "false negatives" would be distributed throughout the sample groups. No plant ever tested negative that was previously identified as infected, suggesting that the assay was a reliable way of assessing the spread of PMWaVs.

PMWaV-3 incidence was not monitored during this study because of the lack of a rapid TBIA assay specific for PMWaV-3 that could accommodate the nearly 40,000 samples processed over the duration of the experiment. Although it is expected that PMWaV-3 will be classified as a distinct species, the genome characteristics of PMWaV-3 are similar to PMWaV-1 $(13,14,24)$. Transmission characteristics of PMWaV-1, PMWaV-2, and PMWaV-3 are also similar $(22,26)$. The incidence of PMWaV-3 in the pineapple hybrid studied was comparable with that of PMWaV-2, approximately $9 \%$ (25). Given the similar incidence of PMWaV-2 and PMWaV-3, it is likely a similar pattern of incidence change could be expected for PMWaV-3. PMWaV-4 and PMWaV-5 were not detected in this hybrid $(26,27)$.

The location of fields can greatly influence the incidence of viruses in the plant material. In our studies, fields 1 and 3 had the largest increases in virus incidences over time. These fields were adjacent to ratoon fields, whereas fields 2 and 4 were surrounded by fallow fields or plant crops that were not taken to ratoon stage. It is possible that fields 1 and 3 were subjected to greater numbers of mealybugs blowing in from adjacent ratoon fields located upwind.

Commercial pineapple crops are clonally propagated through tissue culture or by planting crowns, suckers, slips, or ratoons produced during the previous crop periods. PMWaV-infected pineapple plants do not show visible symptoms of virus infection unless PMWaV-2 and mealybugs are present. Therefore, identification of infected material has relied on serological or molecular assays to identify infected material $(9,25)$. Screening propagation material prior to tissue culture combined with virus elimination techniques can result in virus-free material (23). Although the use of virus-free or virus-resistant planting material in new fields is essential to fully eliminate wilt and virus spread, tissue culture production can be costly and requires more time from initial plantlet development until crop harvest. Presently,

Table 3. Repeated measures analysis of variance for between-subject effects of location within a planting block and field on Pineapple mealybug wilt-associated virus-1 (PMWaV-1) and PMWaV-2 incidence from 3 months after planting until ratoon fruit harvest at 30 months

\begin{tabular}{|c|c|c|c|c|c|}
\hline Source & $\begin{array}{c}\text { Degrees of } \\
\text { freedom }\end{array}$ & $\begin{array}{c}\text { Type III } \\
\text { secretion system }\end{array}$ & Mean square & $F$ value & $P>F$ \\
\hline \multicolumn{6}{|l|}{ PMWaV-1 } \\
\hline Location & 2 & 122.005208 & 61.002604 & 3.88 & 0.0250 \\
\hline Field & 7 & $1,435.351563$ & 205.050223 & 13.05 & $<0.0001$ \\
\hline Location $\times$ field & 14 & 101.078125 & 7.219866 & 0.46 & 0.9469 \\
\hline Error & 72 & $1,131.062500$ & 15.709201 & $\ldots$ & $\ldots$ \\
\hline \multicolumn{6}{|l|}{ PMWaV-2 } \\
\hline Location & 2 & 25.3489583 & 12.6744792 & 1.40 & 0.2535 \\
\hline Field & 7 & 387.1640625 & 55.3091518 & 6.10 & $<0.0001$ \\
\hline Location $\times$ field & 14 & 42.8593750 & 3.0613839 & 0.34 & 0.9864 \\
\hline Error & 72 & 652.3125000 & 9.0598958 & $\ldots$ & $\ldots$ \\
\hline
\end{tabular}

crowns or slips collected from existing plants are used to establish new fields. This means of propagation can provide the large numbers of propagules needed to establish new fields but the large number of plantlets required make virus screening impractical. Collecting pineapple planting materials from regions with the lowest virus incidences is a practical alternative to screening very large numbers of propagules used for planting.

Central regions of planting blocks had less virus increase than the edge or end regions. The lower incidence of PMWaVs in the central regions may be due to fewer wind-borne mealybug vectors reaching the central regions, possibly due to plants at the edges and ends of the planting blocks trapping the insects. Illingworth (11) and Carter (3) have previously referred to MWP as edge wilt. Infected plants along the edges and ends of planting blocks are more exposed to mealybugs. In addition to wind, other contributing factors along the edges may be important. Ants such as big headed ant (Pheidole megacephala) have been shown to contribute to significant increases in mealybug populations $(6,16,21,28)$ and the movement of mealybugs into the fields (12); however, in the results presented here, ants were controlled by insecticides for the duration of the study.

Planting patterns of pineapple in Hawaii are based on a number of factors, including terrain, soil type, environmental conditions, spray boom lengths, and control over forcing and fruit production. Previously, we have shown that the rate of virus spread and subsequent mealybug wilt development is highest between adjacent plants in a row and between adjacent rows within a bed and is less between adjacent rows in different beds (20). The distance between beds is nearly double the distance between rows within a bed. This pattern of secondary spread could be due to mealybugs walking, blowing, or being carried by ants to adjacent plants and suggests limiting the number of rows per bed. Based on the data presented here, planting designs that maximize the amount of internal or central regions may slow the increase of PMWaV incidences and also produce propagation material with the lowest virus incidences. Using one or two rows per bed and maximizing the internal or centrally protected areas may provide a passive means to minimizing virus spread.

\section{ACKNOWLEDGMENTS}

This research was funded, in part, by grants from the Hawaii Department of Agriculture (Contract No. 49048), the Tropical/Subtropical Agricultural Research Program (Project No. HAW0098510145), the United States Department of Agriculture-Cooperative State Research, Education, and Extension Service (USDA-CSREES) Special Research Grants Program-Pest Management Alternatives Program (Project No. HAW00937-G under agreement 2003-34381-13659, and from the USDA-CSREES Regional Integrated Pest Man-
} 
agement Competitive Grants Program-Western Region (Project No. Haw01951-G under agreement 2006-34103-17176). We thank S. Nelson for his critical reading of the manuscript and the reviewers and Senior Editor for their helpful suggestions.

\section{LITERATURE CITED}

1. Borroto, E. G., Cintra, M., Gonzalez, J., Borroto, C., and Oramas, P. 1998. First report of closterovirus-like particles associated with pineapple plants (Ananas comosus cv. Smooth Cayenne) affected with pineapple mealybug wilt in Cuba. Plant Dis. 82:263.

2. Campbell, C. L., and Madden, L. V. 1990. Sampling in epidemiological studies. Pages 370-391 in: Introduction to Plant Disease Epidemiology. John Wiley \& Sons, New York.

3. Carter, W. 1932. Studies of populations of Pseudococcus brevipes (CKL) occurring on pineapple plants. Ecology 13:296-304.

4. Carter, W. 1963. Mealybug wilt of pineapple; a reappraisal. Ann. N. Y. Acad. Sci. 1005:741764.

5. Gambley, C. F., Steele, V., Geering, A. D. W., and Thomas, J. E. 2008. The genetic diversity of ampeloviruses in Australian pineapples and their association with mealybug wilt disease. Australas. Plant Pathol. 37:95-105.

6. German, T. L., Ullman, D. E., and Gunasinghe, U. B. 1992. Mealybug wilt of pineapple. Adv. Dis. Res. 9:241-259.

7. Gunasinghe, U. B., and German, T. L. 1989. Purification and partial characterization of a virus from pineapple. Phytopathology 79:1337-1341.

8. Hu, J. S., Gonsalves, A., Sether, D., and Ullman, D. E. 1993. Detection of pineapple closterovirus, a possible cause of mealybug wilt of pineapple. Acta Hortic. 334: 411-416.

9. Hu, J. S., Sether, D. M., Liu, X. P., Wang, M., Zee, F., and Ullman, D. 1997. Use of a tissue blotting immunoassay to examine the distribution of pineapple closterovirus in Hawaii. Plant Dis. 81:1150-1154.

10. Hu, J. S., Sether, D. M., and Ullman, D. E. 1996. Detection of pineapple closterovirus in pineapple plants and mealybugs using monoclonal antibodies. Plant Pathol. 45:829-836.

11. Illingworth, J. F. 1931. Preliminary report on evidence that mealybugs are an important factor in pineapple wilt. J. Econ. Entomol. 24:877-889.

12. Jahn, G. C., and Beardsley, J. W. 2000. Interactions of ants (Hymenoptera: Formicidae) and mealybugs (Homoptera: Pseudococcidae) on pineapple. Proc. Hawaii Entomol. Soc. 34:181185.

13. Melzer, M. J., Karasev, A. V., Sether, D. M., and $\mathrm{Hu}$, J. S. 2001. Nucleotide sequence, genome organization, and phylogenetic analysis of Pineapple mealybug wilt-associated virus-2. J. Gen. Virol. 82:1-7.

14. Melzer, M.J., Sether, D. M., Karasev, A.V., and $\mathrm{Hu}$, J. S. 2008. Complete nucleotide sequence and genome organization of Pineapple mealybug wilt-associated virus-1. Arch. Virol. 153:707-714.

15. Rohrbach, K. G. 1991. Pineapple: The Plant and Its Culture. Hawaii Institute of Tropical Agriculture and Human Resources, University of Hawaii at Manoa, Hawaii Agric. Exp. Stn. Honolulu.

16. Rohrbach, K. G., Beardsley, J. W., German, T. L., Reimer, N. J., and Sanford, W. G. 1988. Mealybug wilt, mealybugs, and ants on pineapple. Plant Dis. 72:558-565.

17. Sether, D. M., and Hu, J. S. 1998. Corollary analyses of the presence of pineapple mealybug wilt associated virus and the expression of mealybug wilt symptoms, growth reduction, and/or precocious flowering of pineapple. (Abstr.) Phytopathology 88:S80.

18. Sether, D. M., and Hu, J. S. 2001. The impact of pineapple mealybug wilt-associated virus-1 and reduced irrigation on pineapple yield. Australas. Plant Pathol. 0:31-36.

19. Sether, D. M., and Hu, J. S. 2002. Closterovirus infection and mealybug exposure are necessary for the development of mealybug wilt of pineapple disease. Phytopathology 92:928935.

20. Sether, D. M., and Hu, J. S. 2002. Yield impact and spread of Pineapple mealybug wilt associated virus -2 and mealybug wilt of pineapple in Hawaii. Plant Dis. 86:867-874.

21. Sether, D. M., and Hu, J. S. 2006. Reducing the spread of two mealybug-transmitted Pineapple mealybug wilt associated viruses. (Abstr.) Phytopathology 96:S106.

22. Sether, D. M., Hu, J. S., and Ullman, D. E. 1998. Transmission of pineapple mealybug wilt associated virus by two species of mealybugs (Dysmicoccus spp.). Phytopathology 88:1224-1230.

23. Sether, D. M., Karasev, A. V., Okumura, C., Arakawa, C., Zee, F., Kislan, M. M., Busto, J. L., and Hu, J. S. 2001. Differentiation, distribution, and elimination of two different pineapple mealybug wilt associated viruses found in pineapple. Plant Dis. 85:856-864.

24. Sether, D. M., Melzer, M. J., Borth, W. B., and $\mathrm{Hu}$, J. S. 2009. Genome organization and phylogenetic relationship of Pineapple mealybug wilt associated virus-3 and other family Closteroviridae members. Virus Genes 38:414-420.

25. Sether, D. M., Melzer, M. J., Busto, J., Zee, F. and $\mathrm{Hu}$, J. S. 2005. Diversity and mealybug transmissibility of ampeloviruses in pineapple. Plant Dis. 89:450-456.

26. Sipes, B. S., Sether, D. M., and Hu, J. S. 2002. Interactions between Rotylulenchus reniformis and Pineapple mealybug wilt associated virus 1 in pineapple. Plant Dis. 86:933-938.

27. Subere, C. V., Sether, D. M., Zee, F., and Hu, J. S. 2007. Diversity and distribution of Pineapple mealybug wilt-associated viruses (PMWaVs) and pineapple badnaviruses in Hawaii. (Abstr.) Phytopathology 97:S112.

28. Taniguchi, G., Thompson, T., and Sipes, B. 2005. Control of the big-headed ant, Pheidole megacephala (Hymenoptera: Formicidae) in pineapple cultivation using Amdro in bait stations. Sociobiology 45:1-7.

29. Wakman, W., Teakle, D. S., Thomas, J. E., and Dietzgen, R. G. 1995. Presence of a closterolike virus and a bacilliform virus in pineapple plants in Australia. Aust. J. Agric. Res. 46:947958. 